IZA DP No. 5955

Is Internet Job Search Still Ineffective?

Peter Kuhn

Hani Mansour

September 2011

Forschungsinstitut zur Zukunft der Arbeit Institute for the Study of Labor 


\title{
Is Internet Job Search Still Ineffective?
}

\author{
Peter Kuhn \\ University of California, Santa Barbara, \\ NBER and IZA \\ Hani Mansour \\ University of Colorado, Denver \\ and DIW Berlin

\section{Discussion Paper No. 5955 \\ September 2011}

\author{
IZA \\ P.O. Box 7240 \\ 53072 Bonn \\ Germany \\ Phone: +49-228-3894-0 \\ Fax: +49-228-3894-180 \\ E-mail: iza@iza.org
}

\begin{abstract}
Any opinions expressed here are those of the author(s) and not those of IZA. Research published in this series may include views on policy, but the institute itself takes no institutional policy positions.

The Institute for the Study of Labor (IZA) in Bonn is a local and virtual international research center and a place of communication between science, politics and business. IZA is an independent nonprofit organization supported by Deutsche Post Foundation. The center is associated with the University of Bonn and offers a stimulating research environment through its international network, workshops and conferences, data service, project support, research visits and doctoral program. IZA engages in (i) original and internationally competitive research in all fields of labor economics, (ii) development of policy concepts, and (iii) dissemination of research results and concepts to the interested public.
\end{abstract}

IZA Discussion Papers often represent preliminary work and are circulated to encourage discussion. Citation of such a paper should account for its provisional character. A revised version may be available directly from the author. 
IZA Discussion Paper No. 5955

September 2011

\section{ABSTRACT}

\section{Is Internet Job Search Still Ineffective?*}

While the Internet has been found to reduce trading frictions in a number of other markets, existing research has failed to detect such an effect in the labor market. In this paper, we replicate Kuhn and Skuterud's (2004) study - which found that Internet job search (IJS) was associated with longer unemployment durations in 1998/2000 - using comparable data from a decade later. We find that IJS now appears to be effective: it reduces individual workers' unemployment durations by about 25 percent. This finding is robust to controls for workers' AFQT scores and detailed indicators of Internet access. IJS appears to be most effective in reducing unemployment durations when used to contact friends and relatives, to send out resumes or fill out applications, and also to look at ads. We detect no effect of IJS on wage growth between jobs.

JEL Classification: J64

Keywords: Internet, job search, unemployment, durations

Corresponding author:

Peter Kuhn

Department of Economics

University of California

Santa Barbara, CA 93106

USA

E-mail: pjkuhn@econ.ucsb.edu 


\section{Introduction}

Over the past decade, the Internet has been credited for substantial reductions in search frictions in markets ranging from life insurance to apartment rentals (Brown and Goolsbee 2002; Kroft and Pope 2010). In contrast, studies of the Internet's effects on labor markets have been few in number, and on balance find little or no evidence of a friction-reducing effect. For example, Kuhn and Skuterud (2004) find that unemployed workers who look for work on line have longer unemployment durations than comparable non-Internet searchers, while Kroft and Pope (2010) find no evidence that the rapid expansion of Craigslist as a job search tool has affected city-level unemployment rates. ${ }^{1}$ At least on the surface, these results seem puzzling, in view of the dramatic expansion of on-line job search sites as well as the general decline in communication costs associated with the Internet. Both of these changes should increase the arrival rate of matches between job searchers and vacancies, thereby reducing search frictions in labor markets.

In this paper, we provide new evidence relevant to this 'puzzle’ of ineffective Internet job search (IJS) using data on young U.S. jobseekers in the period 2008-09. Our main result is that IJS appears to reduce unemployment durations among these workers by about 25 percent. Specifically, after replicating Kuhn and Skuterud’s (henceforth KS 2004) estimate of a counterproductive effect of IJS using their CPS data for 1998/2000 for this age group, we show that this counterproductive effect is reversed in 2008/2009 in the same regression specification. This reversal holds whether or not we control for a possible source of endogenous selection --

\footnotetext{
${ }^{1}$ Stevenson $(2007,2009)$ finds some evidence suggesting that the Internet may have increased the rate at which employed workers change jobs.
} 
searchers’ AFQT scores - that was not available in the earlier, CPS data. We speculate that significant improvements in technology over this period, ranging from better online job sites to network externalities associated with greater overall Internet penetration itself, might explain this change over time.

Our data also allow us to document a number of new results about how the Internet is used in the job search process, and about which types of job search activity are most facilitated by the Internet. For instance, we document a huge increase in Internet job search over the last decade: between 1998/2000 and 2008/2009, the share of young, unemployed workers who used the Internet to look for work tripled, from 24 to 74 percent. $^{2}$ In contrast to a hypothesis advanced in KS 2004, we find that online search is not disproportionately passive (relative to offline search) in our data. This unexpectedly active nature of online search (at least in 2008/09) might help its effectiveness in the more recent period. Consistent with a different hypothesis advanced by KS 2004, however, we do find that IJS is disproportionately formal, i.e. not involving friends and relatives. That said, in the rare instances where the Internet is used to contact friends and relatives about work, we find that it is very effective in securing reemployment.

\section{Previous Literature}

The impact of Internet use on the functioning of labor markets has been explored in several previous studies. Focusing first on the potential effects on unemployment durations, Kuhn and Skuterud (2004) use data from the December 1998 and August 2000 CPS Computer and Internet Use Supplements to study the impact of online search on the outcomes of

\footnotetext{
${ }^{2}$ All the NLS Internet job search questions include email as a form of Internet use, and should be interpreted accordingly throughout this paper.
} 
unemployed workers. They find that Internet job seekers are positively selected on observables compared to offline job seekers and, as expected, have shorter unemployment durations. Once observable characteristics are held constant, however, the positive impact of Internet use disappears; indeed their estimates indicate a counterproductive effect. KS conclude that either Internet job search does not reduce unemployment durations or that workers who look for jobs online are negatively selected on unobservables. In line with these results, Kroft and Pope (2010) find that the rapid expansion of the website "Craigslist” in different cities during 2005-2007 had no impact on local unemployment rates. This is despite the fact that Craigslist-related job ads are found to crowd out job classifieds in the printed press. Thus, detecting a "general equilibrium" effect of online job search on labor market outcomes remains elusive as well.

Internet use, however, might be more important for on-the-job searchers (Stevenson 2007), especially in light of the increasing number of adults who use the Internet regularly at work (Autor 2001). Stevenson (2007) provides evidence that workers who have access to Internet at work are significantly more likely to transition from one job to another, within the same firm and across employers, compared to workers who do not have access to the Internet at their current job. It is likely, however, that employed workers with access to the Internet at work are selected on unobservables and might have had a higher number of job transitions even absent Internet availability.

It is also possible that the Internet affects labor markets through its impact on the mix of search methods workers use, especially if some search methods are generally more effective at matching workers with firms. A few studies have attempted to evaluate the relative effectiveness of different job search methods, despite the difficulties presented by endogenous job search choice (Holzer 1988; Bortnick and Ports 1992). Osberg (1993), for instance, argues that job 
search methods vary with the business cycle, and that public employment agencies are more effective during recessions. In contrast, using Portuguese data, Addison and Portugal (2002) found that public employment agencies are less effective at securing long-lasting and higher paid jobs. In contrast, several empirical studies suggest that searching for jobs through friends and relatives is a more effective search method compared to others (Blau and Robins 1990; Holzer 1988). To our knowledge, no study has been able to directly assess whether the Internet had an impact on the choice of job search methods. Stevenson (2009) provides suggestive evidence that the rate of Internet penetration into US cities is positively correlated with search intensity, measured either by the overall number of search methods used or by examining specific search methods, but she is unable to distinguish the rates of Internet use in each of the job search methods. Consistent with our findings, her results suggest that higher Internet penetration increases the likelihood of directly contacting an employer.

\section{Data and IJS Time Trends}

As noted, we use data from two sources, roughly a decade apart, to examine time trends in Internet job search and its correlates. For the earlier period, our sample consists of unemployed workers who responded to the December 1998 and August 2000 CPS Computer and Internet Use Supplements to the Current Population Survey (CPS). Data on these workers' subsequent search outcomes were collected by matching individuals to all the subsequent monthly CPS surveys in which they appeared. This is the exact sample used in KS (2004). Internet access and job search rates for persons aged 23-29 in this sample are presented in Row 1 of Table 1. About 24 percent of unemployed 23-29-year-olds looked for work on line at that time; this number rises to 65 percent among the minority of that group who had home internet access. 
For the later period, we use information provided by respondents to wave 12 of the 1997 National Longitudinal Survey of Youth (NLSY97), conducted during 2008-2009 when the respondents were 24-28 years old. ${ }^{3}$ A novel feature of this wave is that, at three points in the interview decision tree, respondents are asked to list which of the twelve CPS job search activities they engaged in. After indicating whether they used each of these methods, respondents are then asked which of those activities involved any Internet use. We use these questions to generate new descriptive information on how young workers use the Internet to look for work (in Section 4) and to study the determinants and outcomes of Internet job search (in Sections 5 and 6 respectively). The exact wording of the NLSY97 job search questions is provided in Appendix A.

The three sets of job search questions in our NLYS97 data allow us to construct measures of Internet job search for four distinct samples of respondents, as follows. First, respondents who were not working at the interview date were asked to list all their current job search methods, including Internet use, as above. We refer to the subset of this group who engaged in at least one active search activity as our unemployed sample; means for the unemployed sample are shown in row 2 of Table 1, and should by construction be directly comparable to row 1 . Comparing rows 1 and 2 of the Table reveals that home Internet access increased from 28.6 to 61.2 percent of unemployed persons over the past decade. Conditional on having home Internet access, the share of unemployed persons who used the Internet in at least one aspect of their job search rose from 64.9 to 86.1 percent. As a consequence of these two developments, the share of young

\footnotetext{
${ }^{3}$ Note that we choose our CPS sample to have one extra year on either side of the NLSY age interval. We do this just to increase our statistical power; essentially nothing changes if we restrict the CPS sample to ages 24-28.
} 
unemployed workers who looked for work on line tripled over this period, from 24.2 to 74.4

percent. $^{4}$

Next, NLSY respondents who were employed at the interview date were asked whether they had engaged in any job search activity in the last three months; if so they were asked the same list of search method questions as above. ${ }^{5}$ We refer to persons who answered these questions and used at least one active search method as employed jobseekers; their means are shown in Row 3. Given home Internet access, employed jobseekers are slightly more likely to look for work on line than unemployed jobseekers; however their greater rate of access gives them about a 10 percentage point advantage in Internet job search over the unemployed group.

Third, the NLSY also asks currently employed workers to "think back when you found your current job with [employer name]”, and to list all the job search methods they used to look for work at that time. ${ }^{6}$ This is by far the largest sample of respondents for whom we observe job search methods in our data. Search indicators derived from this question are presented in row 4 of Table $1 .^{7}$ In this group, only 43.6 percent reported looking for work on line; in part this might reflect the fact that some of these search episodes occurred several years before the survey date.

Finally, row 5 of Table 1 presents statistics for the subset of the above sample who experienced an unemployment spell immediately preceding the start of their current job. Like row 2, the statistics in this row represent Internet job search rates for a sample of unemployment

\footnotetext{
${ }^{4}$ All our results from the NLSY97 use sampling weights to adjust for the systematic oversampling of Blacks and Hispanics in the NLSY.

${ }^{5}$ Strictly speaking, respondents had to be in a 'long-term' job at the survey date (defined by the NLSY as a current job lasting longer than 3 months) to be asked this set of questions.

${ }^{6}$ It would of course also be interesting to know which of the methods used was ultimately responsible for locating the current job. For example, Weber and Mahringer (2008) use information of this nature in estimating the relative effectiveness of various search methods. But our survey question clearly asks respondents to list all the methods they used when they were searching.

${ }^{7}$ For comparability with the previous measures we also restrict this sample to active searchers, i.e. to persons who reported using at least one active search method.
} 
spells. In contrast to row 2, we know the duration of these spells; in fact this is the sample of search spells in which we will estimate the effects of IJS on durations, in Section 6 below. ${ }^{8}$ Overall, 55.3 percent of this group looked for work on line.

\section{How is the Internet Used to Look for Work?}

Table 2 presents a detailed breakdown of the search methods used by currently unemployed workers (the row 2 sample in Table 2), including the use of the Internet for each of those methods. According to Table 2, a typical unemployed worker in the NLSY data used 1.58 out of 9 possible active search methods off line (i.e. without indicating any Internet use); the most common of these was "contacted friends or relatives". The same worker used 1.44 of the 9 possible active methods on line, the most frequent of which was "sent out resumes or filled out applications". Combining on and off-line search, a typical unemployed worker used 3.02 of the 9 possible active methods. Of these, the most Internet-intensive method was sending out resumes or applications: of workers who used this method, 72 percent used the Internet in doing so. Turning to passive search methods, a typical unemployed worker used .74 out of 3 possible passive methods in our data; the vast majority of this passive activity was "looking at ads".

To our knowledge, Table 2 presents the first available evidence on how unemployed workers actually use the Internet in their job search activities. As such, it contains at least three noteworthy results. First is the relatively wide range of 'traditional' job search activities, ranging from direct employer contact to contacting a public employment agency, in which the Internet is used: aside from contacting friends or relatives, at least one third of the workers using each of the twelve CPS job search activities used the Internet in their search. Overall, if we measure

\footnotetext{
${ }^{8}$ See Section 6 for additional details on how this sample was constructed.
} 
search activity both on and off line simply by counting the number of methods used, ${ }^{9}$ the mean share of total job search activity that is conducted via the Internet is about 48 percent (the bottom right number in the Table). Since this number was likely much lower in 1998/2000, it is perhaps not surprising that IJS did not appear to be effective at that time.

Second, as already noted, is the widespread use of the Internet in both active and passive search methods. In attempting to understand their unexpected findings for the effects of IJS on unemployment durations, KS (2004) speculated that Internet job searchers might consist disproportionately of casual and unmotivated jobseekers who mostly engage in low-cost, lowreturn activities such as looking at Internet job boards. According to our data, this is not the case: Simply “looking at ads” constituted .32/1.81 = 17.7 percent of unemployed workers’ online search activity, compared to $0.30 / 1.96=15.3$ percent of their off-line activity. Also, as the last row of Table 2 indicates, 20 percent of Internet search is classified as passive, compared to 19 percent of off-line search.

Third, and consistent with a different hypothesis advanced in KS 2004, Internet job search is disproportionately formal, as opposed to informal (where we define latter as contacting friends and relatives). While 0.44/1.96 = 22 percent of offline search involves contacting friends and relatives, this is true for only 6 percent of online search. In fact, according to column 4 of Table 2, contacting friends and relatives is the least Internet-intensive of all the 12 CPS search methods: only 20 percent of people who use this method say they used the Internet to do so. We find this low use of the Internet for informal job search surprising in view of the rapid growth of on-line social networking (especially among the young), but in 2008/9 social media may have

\footnotetext{
${ }^{9}$ Counting the number of methods used is a widely-used measure of search effort or intensity. See for example Blau and Robins (1990).
} 
linked young people mostly with other young people. As social media continue to expand into other demographics, they may become a more effective tool in job search.

Versions of Table 2 for two other populations -employed searchers, and workers who experienced an unemployment spell immediately preceding their current job—are available in Appendix Tables B1 and B2. These Tables confirm the main conclusions we drew from Table 2: Internet job search is widely used to undertake almost all the traditional job search methods, with the exception of informal channels. Moreover, the Internet is used in similar proportions among active and passive search methods.

\section{Who looks for work on line?}

Table 3 presents coefficient estimates from linear probability models in which the dependent variable equals one if the respondent is currently looking for work on line, and zero otherwise. Results are presented for three samples of respondents, all of whom are unemployed at the relevant survey date. In columns (1) and (2), the sample is exactly the one used in KS (2004), from CPS interviews in December 1998 and August 2000. Columns (3) and (4) retain only respondents aged 23-29 from that sample, for comparability with the NLSY97 data. Finally, columns (5)-(7) present results for NLSY respondents who were unemployed when interviewed in 2008-2009, when the respondents were 24-28 years old. Covariate lists and definitions were selected to be as comparable as possible between the CPS and NLSY datasets; in addition to the covariates shown, all regressions included controls for age, plus a full set of fixed effects for whether each of the 12 possible BLS search methods was used. ${ }^{10}$

\footnotetext{
${ }^{10}$ The rationale for the latter control is to hold total search effort (and its mix across methods) constant, in order to focus purely on the decision to look on line or not. That said, the results do not change appreciably if we exclude these controls.
} 
Not surprisingly, home Internet access is a strong predictor of IJS in all three samples. Also as we would expect, the size of the coefficient is considerably smaller in 2008/9, when the mean level of Internet penetration is considerably closer to saturation. All three data sets also show a strong, and highly statistically significant association of IJS with education levels: without Internet access or AFQT controls, unemployed respondents with a university degree are over 40 percentage points more likely to look for work on line than high school dropouts. This gap falls to 20 percentage points when controlling for Internet access in 1998/00 or for AFQT in 2008/09.

Table 3's results for race are of particular interest in view of the past decade's literature on the "digital divide” (e.g. Sevron 2002, Fairlie 2004) and also given an earlier literature on racial gaps in job search methods and outcomes (e.g. Holzer 1987, 1988). In the CPS data from around the turn of the century, unemployed Blacks and Hispanics were less likely than Whites to look for work on line, but this gap could be completely explained by racial gaps in Internet access. A decade later, there is no racial gap in IJS among unemployed workers, reflecting in part the greater ubiquity of Internet access and use. However, when we compare Blacks and Whites with identical AFQT scores (which is only possible in 2008/9), unemployed Blacks are significantly more likely to look for work on line than Whites. This is consistent with Holzer's argument that similarly-qualified Blacks rely more on formal networks than Whites, perhaps due to a relative paucity of informal contacts in the world of work.

Finally, while the standard errors are high in the smaller samples, the overall similarity of comparably-specified regressions for Internet job search between the CPS overall sample, the CPS ages 23-29 sample, and the NLSY97 sample adds to our confidence that any differences we see in the estimated effects of IJS in the next section are in fact due to changes in IJS 
effectiveness, rather than changes in the population under study. Identically-specified IJS regressions for two other NLSY samples -employed jobseekers, and the sample of workers used in the following section's duration analysis-- are presented in Appendix Table B3. They also show very similar patterns, including a positive effect of being Black in the presence of AFQT controls, which is statistically significant in the larger of the two samples.

\section{IJS and Unemployment Durations.}

Parallel to Table 3, Table 4 presents estimates of regression models for two CPS samples and one NLSY sample, but now the dependent variable in all cases is the log of the respondent's unemployment duration. For the CPS regressions in columns 1-4, the sample is identical to the one in KS 2004 --all persons who were unemployed at the December 1998 and August 2000 survey dates--, and the unemployment duration is the time between those dates and the respondent's date of reemployment. Because -due to the CPS interview structure-- this duration is only known in observation-specific intervals that in some cases are quite wide, we adjust for the interval nature of the data using interval-normal regression. In other words, we assume that mean of log duration is linear in the covariates, that the conditional-on-observables distribution of log durations is normal, and use maximum likelihood methods to infer the effects of the covariates given the interval in which the realized duration lies. ${ }^{11}$

In addition to the internet search indicator itself, all the regressions in Table 4 contain the same covariates as in Table 3, which as noted are defined the same way in both the CPS and

\footnotetext{
${ }^{11}$ This accelerated failure time (AFT) procedure (see for example Kiefer 1988) is a simplified version of the estimation procedure used in KS 2004. KS 2004 provides a more detailed discussion and demonstrates that this class of AFT models is consistent with a wide and familiar group of proportional hazard models.
} 
NLSY97 data sets. ${ }^{12}$ Consistent with KS 2004, columns 1 and 2 of Table 4 show that IJS appears to be counterproductive, as it is associated with longer unemployment durations. Also consistent with KS 2004, the estimated effect is almost twice as strong (amounting to a 22-29 percent increase in unemployment durations) when we add controls for home Internet access. ${ }^{13}$ This is consistent with the notion that 'naïve' comparisons of Internet and non-Internet searchers are contaminated by positive selection of persons with internet access; once we control for this bias, the true ‘counterproductive’ effects of IJS become apparent. Columns 3 and 4 of Table 4 are identical to columns 1 and 2, except that they restrict the sample in the CPS data to respondents between the ages of 23 and 29. While this raises the standard errors, the point estimates are similar, and if anything suggest an even more counterproductive effect of IJS.

Columns 5 and 6 of Table 4 estimate a model of log unemployment durations in the NLSY97 data that is as similar as possible to columns 3 and 4. Since our sample of workers who are unemployed at the NLSY97 survey date is very small, and since we do not observe their search outcomes after the survey date, we construct a sample of unemployment durations that is representative of the outflow from unemployment using the NLSY's questions about how the respondent looked for his/her current job. Specifically, we use the sample of unemployment spells that ended in employment during a given period (specifically January 2007 through the

\footnotetext{
${ }^{12}$ There are only two differences between the CPS and NLSY specifications in Table 4. The first stems from the fact that our CPS durations are measured as time from the interview until reemployment. To control for both the sorting and causal effects of time already spent unemployed, the CPS regressions include a control for elapsed unemployment duration at the survey date. Second, since the NLSY samples spells as they end rather than as they start, we replace the survey year dummy in the CPS data with fixed effects for the year the unemployment spell ended in the NLSY data. We include these dataset-specific covariates because we judge them to be theoretically appropriate; that said, none of our results for unemployment durations change materially if we drop any or all of these covariates from our regressions.

${ }^{13}$ The only differences between columns 1 and 2 of Table 4 and Table 4 in KS 2004 are thus (a) a shorter list of covariates, chosen to be identical with the covariate list in the NLSY data, and (b) the less flexible parameterization of the baseline hazard function inherent in a log duration specification. The latter choice is purely for simplicity and transparency; later in this section we show that our main NLSY results remain unchanged when we allow for a more flexible baseline hazard.
} 
survey date), and measure these spells' durations as the time between the end of the respondent's previous job and the start date of the current one. While this approach is less typical than inflowbased samples in empirical studies of unemployment durations, in steady state a sample of outflows is just as representative as a sample of inflows. ${ }^{14}$ In both cases, it is of course important to treat censored spells appropriately in the estimation.

In more detail, to construct our sample of unemployment durations, we start with all individuals who currently hold a single job, and who started that job between January 1, 2007 and the survey date. We then keep only those individuals who experienced a jobless spell immediately before starting the current job, and who reported that they used at least one active method to search for work during that spell. The latter restriction ensures that we are looking at unemployment spells (as opposed to jobless spells more generally) and is identical to the definition of unemployment in our CPS sample. Finally, we construct the durations of these unemployment spells by looking backwards in the data (as far as January 1, 2005) until we encounter the end of any previous job. ${ }^{15}$ If we cannot find a previous job in this interval, the unemployment spell is coded as censored at that date, i.e. we know the spell started before January 1, 2005, but not exactly when.

Turning to the results, we note first that, while the standard errors are sometimes high, the effects of the control variables in columns 5 and 6 are similar to those in columns 3 and 4 . In particular, Hispanic workers have unemployment spells than Whites, and marriage dramatically lowers young men’s unemployment durations, but not women’s. Leaving the previous job

\footnotetext{
${ }^{14}$ We address pure time effects due to business cycles and other factors by including fixed effects for the year in which the unemployment spell ended.

${ }^{15}$ We have experimented with alternative window periods for sampling new jobs (i.e. starting at dates other than January 2007), and with alternative limits for how far back we search for previous jobs (i.e. other than January 2005). Our main results on IJS and unemployment durations are not sensitive to these choices.
} 
involuntarily is associated with a huge increase in durations. The only coefficients that differ markedly between the two samples are for gender and being Black, though in both cases the standard errors are high.

Moving to the effects of IJS, however, its coefficient has opposite signs in the CPS and NLSY97 data: IJS now appears to reduce unemployment durations by about 25 percent. Even though having home Internet access is still associated with shorter unemployment spells, adding this control no longer affects the estimated IJS effect. Nor, as column 7 shows, does adding a control for unobserved individual ability that was unavailable in the CPS: AFQT. Indeed, the estimated benefits of IJS are slightly stronger in the presence of AFQT controls than in their absence.

In order to assess the robustness of our main result, Table 5 presents estimates from three additional regression specifications in the NLSY97. Aside from the changes discussed below, all specifications are identical to column 7 in Table 4; thus controls for home Internet access and AFQT are always present. In column 1, we replace the indicator for whether the respondent used the Internet in any of his/her job search activities by a more continuous measure. Specifically, the Internet intensity measure used in the top row of Table 5 gives the share of the number of job search methods used by the respondent (from one to 12) that involved some Internet use. ${ }^{16}$ Consistent with the notion that this reduces the measurement error inherent in a crude dichotomous IJS indicator, the coefficient on Internet search increases in both size and significance. Now, moving from no Internet use to 100 percent Internet use in job search

\footnotetext{
${ }^{16}$ Thus, for example, if the respondent used five of the twelve possible search methods and two of these involved some Internet use, her Internet intensity measure equals .4.
} 
reduces unemployment durations by about 37 percent, an effect which is significant at the 5 percent level.

Column 2 of Table 5 addresses the possibility that our indicator for home Internet access might not fully control for unobserved personal characteristics that raise both Internet use and the job-finding rate. Here, in addition to the home Internet access dummy, we also include separate indicator variables for whether the respondent has Internet access at six additional types of locations: school, work, a public library, an Internet café, a friend, or another location. ${ }^{17}$ This has very little effect on the estimates. Finally, column 3 addresses the notion that all the log duration models estimated so far impose strong functional form assumptions on the time structure of the underlying hazard rate. Therefore we estimate a Cox partial likelihood model for the re-employment hazard on the same covariates as in column 2. While the coefficient magnitudes are not directly comparable to column 2, the sign and statistical significance of the coefficients strongly confirm our other results. Now, Internet job search is estimated to raise unemployed workers' re-employment hazard by about 25 percent; this effect is significant at the one percent level. Plots of the estimated survivor curve for IJS intensity levels of zero and the sample mean (.42) are provided in Figure 1; they show an effect of IJS throughout the job search process. After about 30 weeks of unemployment, Figure 1 shows that about 20 percent of workers with average IJS intensity are still unemployed, compared to about 24 percent of workers who look for work off line only.

\footnotetext{
${ }^{17}$ Recall that all of our Internet access variables refer to the survey date. Thus, they may be, in part endogenous: persons who find a new job quickly might use their re-employment earnings to buy more Internet access, or might be more likely to find a job that provides Internet access. (Recall that all respondents are employed at the survey date because we are sampling from the inflow to employment). If anything, however, endogeneity of this form will lead us to underestimate the benefits of Internet search when we add these controls.
} 
Finally, in order to try to identify which particular types of job search activity are most facilitated by Internet use, we re-estimated column 3 of Table 5, replacing the Internet intensity variable with twelve dummy variables, indicating whether the Internet was used for each specific job search method, ranging from direct employer contact to "other passive” methods. Not surprisingly, most of the resulting coefficients were statistically insignificant; it is a challenge to disentangle this many effects in our small sample, especially where a number of the search methods are only rarely used. Still, the following results seem noteworthy. First, using the most common form of IJS, --sending out resumes or filling applications-- increases a worker's jobfinding hazard by about 20 percent (coefficient $=.203, p=.048){ }^{18}$ Second, using the Internet to contact friends and relatives raises the job-finding rate by 36 percent, an effect which is statistically significant at the 1 percent level. Thus, even though contacting friends and relatives on line is a relatively rare form of IJS, it appears to be highly effective. Finally, the only other form of IJS with a statistically significant effect was "looked at ads" (coefficient $=.336, p=$ .012). This is intriguing in view of the fact that the Bureau of Labor Statistics classifies looking at ads as a passive job search method. Perhaps looking at Internet job ads is different, due to the ease with which a passive 'looker’ can become active with as little as the click of a mouse.

\section{IJS and Wage Changes.}

Does looking for work on line help unemployed workers to find a better job than they would otherwise have found? Table 6 addresses this question in the NLSY data by regressing the change in the log wage between the respondent's previous and current job on exactly the

\footnotetext{
${ }^{18}$ Recall that our regression includes a full set of controls for the use of the twelve methods themselves (whether onor offline). Thus this effect should be interpreted as relative to workers who use the same method offline; the same applies to all comparisons in this paragraph.
} 
same sample and covariates that were used in Table $5 .{ }^{19}$ Unsurprisingly and consistent with essentially all search models, workers who left their previous job involuntarily experience a wage change between their old and new job that is about 12 log points lower than workers who quit their previous job. Workers with a university degree experience much more wage growth across jobs than other workers in this data; this likely reflects these young workers’ first transitions into 'career' jobs related to their education. That said, the estimated effects of IJS on the amount of between-job wage growth are small in magnitude (from minus four to zero percent) and statistically insignificant. Thus, in our data, the benefits of looking for work on line for young unemployed workers appear to be confined to finding a new job faster, not finding a better one.

\section{Conclusion.}

Has the Internet reduced frictions in labor markets? And is the unemployment rate lower today that it would have been, if workers and firms were unable to search for each other using the Internet? In this paper, we argue that a necessary condition for this to be true is that in any given labor market, identical unemployed individuals differentiated only by whether they use the Internet in their job search should experience different search outcomes, with the Internetsearcher achieving better results. Of course, as is well known, this is not a sufficient condition for an aggregate unemployment-reducing effect of the Internet because of search externalities: more effective search by some workers may reduce the job-finding rate of other workers, so the

\footnotetext{
${ }^{19}$ Since wage information is collected in only one out of every four CPS surveys, analysis of wage changes is not feasible.
} 
aggregate effect of a technology that increases the offer arrival rate can be different from its partial-equilibrium effect, and can be either welfare-enhancing or reducing. ${ }^{20}$

In this paper, we study whether the above necessary condition is satisfied in data on young U.S. workers taken from two points in time: 1998/2000 and 2008/2009. While we cannot compare literally identical workers looking for work in different ways, we can compare observationally identical workers in the presence of a detailed set of covariates, including one the worker's AFQT score- that has not been used in any previous studies of Internet job search. We find that, while IJS appeared to be either ineffective or counterproductive a decade ago, it is now associated with about a 25 percent reduction in unemployment durations. No effect of IJS on between-job wage growth was found.

What might account for the above change in the effectiveness of Internet job search? One obvious candidate is, of course, design improvements in the main Internet job search sites, including not only commercial sites like Monster and Careerbuilder, but also governmentoperated sites plus a long list of local and occupation/industry-specific job boards. This hypothesis is certainly consistent with our finding that the Internet is highly effective when used to look at ads, to send out resumes, and to fill applications. That said, another candidate for explaining the increased effectiveness of IJS is just the dramatic rise in overall Internet penetration and connectivity, as reflected in the huge increase in IJS documented in this paper. Simply because the Internet now connects each worker to many more firms (and vice versa) in several new and low-cost ways, it may have become a more powerful tool in the job search process than it was a decade ago.

\footnotetext{
${ }^{20}$ In order to detect such an aggregate effect, a research design would need to take a market-level approach rather than comparing observationally identical individuals within a given market. To our knowledge, Kroft and Pope (2010) is the only study that has taken such an approach.
} 
Finally, while young unemployed workers made very little use of the Internet to contact friends and relatives about jobs in 2008/09, our estimates indicate that these rare contacts were, in fact, highly effective in securing jobs. With the continuing growth of online social media, this may open up even greater opportunities for the Internet to reduce search frictions in labor markets in the future. 


\section{References}

Addison, John T. and Pedro Portugal. “Job Search Methods and Outcomes” Oxford Economic Papers, 54(3) (July 2002): 505-33

Autor, David H. “Wiring the Labor Market” Journal of Economic Perspectives, 15(1) (Winter 2001): 2540

Blau, David M., and Philip K. Robins. "Job Search Outcomes for the Employed and Unemployed” Journal of Political Economy, 98(3) (June 1990): 637-55

Bortnick, Steven M. and Michelle H. Ports. "Job Search Methods and Results: Tracking the Unemployed” Monthly labor Review, 115(12) (December 1992): 29-35

Brown, Jeffrey and Austan Goolsbee. "Does the Internet Make Markets More Competitive? Journal of Political Economy, 110(3) (June 2002): 481-507

Fairlie, Robert W. "Race and the Digital Divide” The B.E. Journal of Economic Analysis and Policy, volume 3, issue 1. (2004)

Holzer, Harry J. "Informal Job Search and Black Youth Unemployment." American Economic Review, June 1987, 77(3), pp. 446-52.

Holzer, Harry J. "Search Method Use by Unemployed Youth." Journal of Labor Economics, January 1988, 6(1), pp. 1-20.

Kiefer, Nicholas M. “Economic Duration Data and Hazard Functions.” Journal of Economic Literature, June 1988, 26(2), pp. $646-79$.

Kroft, Kory and Devin Pope. "Does Online Search Crowd Out Traditional Search and Improve Matching Efficiency? Evidence from Craigslist,” unpublished paper, 2010.

Kuhn, Peter and Mikal Skuterud. “Job Search Methods: Internet versus Traditional”, Monthly Labor Review, October 2000: 3-11. (with Mikal Skuterud).

Kuhn, Peter and Mikal Skuterud. “Internet Job Search and Unemployment Durations” American Economic Review 94(1) (March 2004): 218-232

Osberg, Lars. "Fishing in Different Pools: Job-Search Strategies and Job-Finding Success in Canada in the Early 1980s” Journal of Labor Economics, 11(2) (April 1993): 348-386

Sevron, Lisa J. Bridging the digital divide : technology, community, and public policy. Malden, MA: Blackwell, 2002.

Stevenson, Betsey. “The Internet and Job Search”, In David Autor, ed. Labor Market Intermediation Chicago: University of Chicago Press, 2009.

Stevenson, Betsey. “The Impact of the Internet on Worker Flows” Unpublished paper, The Wharton School, University of Pennsylvania, 2007.

Weber, Andrea and Helmut Mahringer. "Choice and Success of Job Search Methods” Empirical Economics, vol. 35, no. 1, August 2008, pp. 153-78 
Table 1: Fraction of Persons with Internet Access and Engaging in Internet Job Search, by Period and Labor Force Status

\begin{tabular}{|c|c|c|c|c|}
\hline Period and Sample: & $\begin{array}{l}\text { Fraction with Home } \\
\text { Internet Access }\end{array}$ & $\begin{array}{c}\text { Fraction looking for } \\
\text { work on line, given } \\
\text { home Access }\end{array}$ & $\begin{array}{c}\text { Fraction looking for } \\
\text { work on line }^{b}\end{array}$ & Sample Size $^{c}$ \\
\hline & (1) & $(2)$ & (3) & (4) \\
\hline \multicolumn{5}{|l|}{ 1998/2000 (CPS Data) } \\
\hline 1. Unemployed & 28.6 & 64.9 & 24.2 & 669 \\
\hline \multicolumn{5}{|l|}{ 2008/2009 (NLSY97 Data) } \\
\hline 2. Unemployed & 61.2 & 86.1 & 74.4 & 474 \\
\hline 3. Employed Jobseekers & 81.3 & 89.3 & 85.3 & 441 \\
\hline 4. During search for current job (all) & 77.8 & 48.0 & 43.6 & 4,412 \\
\hline 5. During search for current job (unemployed) & 74.4 & 63.6 & 55.3 & 1,166 \\
\hline
\end{tabular}

Notes on Table 1: CPS samples restricted to ages 23-29 at the survey date; NLSY sample is $24-28$ years old at the survey date.

${ }^{\text {a }}$ Refers to the survey date in all cases

${ }^{b}$ Does not equal (1) times (2) because it is possible to job search on line without home Internet access.

${ }^{\mathrm{c}}$ Refers to column 3.

Data from 1998/2000 are from the December 1998 and August 2000 CPS Computer and Internet Supplements; Data from 2008/2009 are from Wave 12 of the NLSY97. All NLSY97 data use sampling weights.

"Unemployed" in both surveys refers to a person currently not working, using at least one active search method according to the CPS definition (see Table 3 for the list of active methods).

"Employed Job Searchers" are currently working, and using at least one active search method according to the CPS definition (see Table 3 for the list of active methods). 
Table 2: Search Methods of Unemployed Workers, NLSY97

\begin{tabular}{|c|c|c|c|c|}
\hline Method & $\begin{array}{l}\text { (1) } \\
\text { Share of workers } \\
\text { using method off } \\
\text { line }\end{array}$ & $\begin{array}{c}\text { (2) } \\
\text { Share of workers } \\
\text { using method on } \\
\text { line }\end{array}$ & $\begin{array}{c}(3) \\
\text { Share of workers } \\
\text { using method, total } \\
(1+2)\end{array}$ & $\begin{array}{c}(4) \\
\text { Share of method } \\
\text { users doing so on } \\
\text { line }(2 / 3)\end{array}$ \\
\hline \multicolumn{5}{|l|}{ Active Search Methods: } \\
\hline 1. Contacted employer directly & 0.36 & 0.29 & 0.65 & 0.45 \\
\hline 2. Contacted public employment agency & 0.19 & 0.19 & 0.38 & 0.50 \\
\hline 3. Contacted private employment agency & 0.07 & 0.08 & 0.15 & 0.53 \\
\hline 4. Contacted friends or relatives & 0.44 & 0.11 & 0.55 & 0.20 \\
\hline 5. Contacted school/university employment center & 0.05 & 0.06 & 0.11 & 0.55 \\
\hline 6. Sent out resumes or filled out applications & 0.24 & 0.48 & 0.72 & 0.67 \\
\hline 7. Checked unions or professional registers & 0.03 & 0.03 & 0.06 & 0.50 \\
\hline 8. Placed or answered ads & 0.16 & 0.17 & 0.33 & 0.52 \\
\hline 9. Other active methods & 0.04 & 0.03 & 0.07 & 0.43 \\
\hline A: Total active search methods (sum of (1)-(9)) & 1.58 & 1.44 & 3.02 & 0.48 \\
\hline \multicolumn{5}{|l|}{ Passive Search Methods: } \\
\hline 10. Looked at ads & 0.30 & 0.32 & 0.61 & 0.52 \\
\hline 11. Attended job training programs or courses & 0.06 & 0.03 & 0.09 & 0.33 \\
\hline 12. Other passive methods & 0.02 & 0.02 & 0.04 & 0.50 \\
\hline B: Total passive search methods (sum of (10)-(12)) & 0.38 & 0.37 & 0.74 & 0.49 \\
\hline Total number of search methods $(A+B)$ & 1.96 & 1.81 & 3.76 & 0.48 \\
\hline Share of active methods in total search $(A /(A+B))$ & 0.81 & 0.80 & 0.80 & - \\
\hline
\end{tabular}

Notes on Table 2: Sample size of unemployed workers is 474 . Sample weights are applied. 
Table 3: Determinants of Internet Job Search among Unemployed Workers

\begin{tabular}{|c|c|c|c|c|c|c|c|}
\hline & \multicolumn{2}{|c|}{ CPS, All Ages } & \multicolumn{2}{|c|}{ CPS, Ages 23-29 } & \multicolumn{3}{|c|}{ NLSY97 } \\
\hline & $(1)$ & $(2)$ & (3) & (4) & (5) & (6) & (7) \\
\hline \multirow[t]{2}{*}{ Home Internet Access } & & $.38229 * * *$ & & $.45686 * * *$ & & $.22130 * * *$ & $.19658 * * *$ \\
\hline & & $(.01237)$ & & $(.03405)$ & & $(.05336)$ & $(.06035)$ \\
\hline \multirow[t]{2}{*}{ AFQT } & & & & & & & $.08775^{* * *}$ \\
\hline & & & & & & & $(.03064)$ \\
\hline \multirow[t]{2}{*}{ Black } & $-.06635 * * *$ & .01271 & $-.07877^{* *}$ & -.01929 & .02934 & .08188 & $.17064^{* * *}$ \\
\hline & $(.01508)$ & $(.01383)$ & $(.03794)$ & $(.03383)$ & $(.05132)$ & $(.05290)$ & $(.05821)$ \\
\hline \multirow[t]{2}{*}{ Hispanic } & $-.04725 * * *$ & .02009 & -.04071 & .01399 & -.00676 & .01691 & .03731 \\
\hline & $(.01710)$ & $(.01556)$ & $(.04254)$ & $(.03782)$ & $(.06048)$ & $(.05938)$ & $(.07175)$ \\
\hline \multirow[t]{2}{*}{ Female } & .00825 & $.02376^{*}$ & .04453 & $.05683^{*}$ & .06093 & .05216 & .08284 \\
\hline & $(.01406)$ & $(.01268)$ & $(.03501)$ & $(.03096)$ & $(.04622)$ & $(.04586)$ & $(.05247)$ \\
\hline \multirow[t]{2}{*}{ Involuntary Job Loss } & .01657 & $.02174^{*}$ & -.02518 & -.01174 & .01606 & -.00475 & .01542 \\
\hline & $(.01255)$ & $(.01131)$ & $(.03179)$ & $(.02811)$ & $(.04338)$ & $(.04199)$ & $(.04639)$ \\
\hline Some high school & $(.02727)$ & $(.02459)$ & (.07835) & $(.06925)$ & $(.10361)$ & $(.10104)$ & $(.12036)$ \\
\hline \multirow[t]{2}{*}{ High School Degree } & $.08029 * * *$ & .03521 & .03316 & .01069 & $.20293^{*}$ & .14165 & .05047 \\
\hline & $(.02649)$ & $(.02391)$ & $(.07454)$ & $(.06590)$ & $(.10476)$ & $(.10220)$ & (.11987) \\
\hline \multirow[t]{2}{*}{ Some College } & $.24308 * * *$ & $.13371^{* * *}$ & $.23150 * * *$ & .09768 & $.35580 * * *$ & $.27693 * * *$ & .12950 \\
\hline & $(.02779)$ & $(.02528)$ & $(.07596)$ & $(.06787)$ & (.10599) & (.10577) & $(.12219)$ \\
\hline \multirow[t]{2}{*}{ University Degree } & $.40088 * * *$ & $.21254^{* * *}$ & $.46712 * * *$ & $.21980 * * *$ & $.45436 * * *$ & $.36420 * * *$ & .19344 \\
\hline & $(.02965)$ & $(.02740)$ & $(.08024)$ & (.07327) & $(.10780)$ & (.10804) & (.12699) \\
\hline \multirow[t]{2}{*}{ Married } & $.07082 * * *$ & $.03804^{* *}$ & .01293 & .05680 & $.15524^{* *}$ & $.13637^{*}$ & .10660 \\
\hline & $(.01931)$ & $(.01742)$ & $(.05250)$ & $(.04651)$ & $(.07571)$ & $(.07653)$ & $(.07707)$ \\
\hline \multirow[t]{2}{*}{ Married*Female } & $-.04810^{*}$ & $-.05809 * * *$ & -.02231 & -.06998 & $-.18363^{*}$ & -.17137 & -.17955 \\
\hline & $(.02492)$ & $(.02245)$ & $(.06826)$ & $(.06043)$ & $(.11099)$ & $(.10780)$ & $(.11765)$ \\
\hline Observations & 4139 & 4139 & 669 & 669 & 455 & 450 & 349 \\
\hline
\end{tabular}

Robust standard errors in parentheses

$* * * p<0.01, * * p<0.05, * p<0.1$

Notes to Table 3: Dependent variable equals one if the respondent engaged in any internet job search, and zero otherwise. The sample for all columns is workers who were unemployed at the interview date. All regressions control for age effects (ten-year bins in columns 1 and 2, and single years of age in columns 3-7), plus fixed effects for whether each of the twelve CPS search methods was used. CPS regressions include a fixed effect for the August 2000 survey date. 
Table 4: Determinants of Log Unemployment Durations

\begin{tabular}{|c|c|c|c|c|c|c|c|}
\hline & \multicolumn{2}{|c|}{ CPS, All Ages } & \multicolumn{2}{|c|}{ CPS, Ages 23-29 } & \multicolumn{3}{|c|}{ NLSY97 } \\
\hline & $(1)$ & $(2)$ & $(3)$ & $(4)$ & $(5)$ & $(6)$ & $(7)$ \\
\hline \multirow[t]{2}{*}{ Search online } & $.12547 * *$ & $.21695 * * *$ & .17985 & $.28796 *$ & $-.25843^{*}$ & $-.23102 *$ & $-.27379 *$ \\
\hline & $(.06110)$ & $(.06900)$ & $(.14678)$ & $(.17114)$ & $(.13567)$ & $(.13681)$ & $(.14956)$ \\
\hline \multirow[t]{2}{*}{ Home Internet Access } & & $-.17564 * * *$ & & -.20113 & & -.15134 & -.18579 \\
\hline & & $(.06183)$ & & $(.16422)$ & & $(.13782)$ & $(.15008)$ \\
\hline \multirow[t]{2}{*}{ AFQT } & & & & & & & -.12008 \\
\hline & & & & & & & $(.07553)$ \\
\hline \multirow[t]{2}{*}{ Black } & $.16529 * *$ & $.13820 * *$ & .18092 & .17114 & .08366 & .06667 & -.03852 \\
\hline & $(.06509)$ & $(.06575)$ & $(.15025)$ & $(.15064)$ & $(.11526)$ & $(.11562)$ & (.13779) \\
\hline \multirow[t]{2}{*}{ Hispanic } & .11116 & .08547 & .21813 & .20549 & $.23087^{*}$ & $.22457^{*}$ & .21495 \\
\hline & $(.07178)$ & $(.07230)$ & $(.16985)$ & $(.17022)$ & $(.12301)$ & $(.12266)$ & $(.14075)$ \\
\hline \multirow[t]{2}{*}{ Female } & -.02527 & -.03590 & -.00121 & -.01351 & $.24041^{*}$ & $.24233^{*}$ & .22114 \\
\hline & $(.05868)$ & $(.05875)$ & $(.13424)$ & (.13459) & $(.13002)$ & $(.13067)$ & $(.14172)$ \\
\hline \multirow[t]{2}{*}{ Involuntary Job Loss } & .05329 & .04989 & $.23734^{*}$ & $.23124^{*}$ & $.37371^{* * *}$ & $.38057 * * *$ & $.39800 * * *$ \\
\hline & $(.05085)$ & $(.05082)$ & $(.12267)$ & (.12279) & $(.12375)$ & $(.12382)$ & $(.13271)$ \\
\hline \multirow[t]{2}{*}{ Some high school } & .09564 & .11182 & .06512 & .06822 & .01909 & .01537 & -.03571 \\
\hline & $(.11699)$ & $(.11697)$ & $(.30967)$ & $(.31001)$ & (.29931) & $(.30267)$ & $(.37376)$ \\
\hline \multirow[t]{2}{*}{ High School Degree } & -.01501 & .00110 & -.18597 & -.17764 & -.28364 & -.26874 & -.27748 \\
\hline & $(.11281)$ & $(.11276)$ & $(.29724)$ & $(.29766)$ & $(.28951)$ & $(.29242)$ & $(.36212)$ \\
\hline \multirow[t]{2}{*}{ Some College } & -.01115 & .01960 & -.15189 & -.11805 & -.37452 & -.33598 & -.25704 \\
\hline & $(.11904)$ & $(.11932)$ & (.30707) & $(.30854)$ & $(.28423)$ & $(.28907)$ & $(.36236)$ \\
\hline \multirow[t]{2}{*}{ University Degree } & -.06884 & -.01106 & -.48832 & -.42326 & $-.48693^{*}$ & -.43439 & -.24525 \\
\hline & $(.12681)$ & $(.12825)$ & $(.32058)$ & $(.32544)$ & $(.28874)$ & $(.29542)$ & $(.37549)$ \\
\hline \multirow[t]{2}{*}{ Married } & -.11288 & -.10803 & $-.54672 * * *$ & $-.56788 * * *$ & $-.57939 * * *$ & $-.56825 * * *$ & $-.67350 * * *$ \\
\hline & $(.07633)$ & $(.07630)$ & $(.18726)$ & $(.18800)$ & $(.17345)$ & $(.17280)$ & $(.18828)$ \\
\hline \multirow[t]{2}{*}{ Married*Female } & .13542 & .14945 & $.63027^{* *}$ & $.66199 * * *$ & $.77601 * * *$ & $.76552 * * *$ & $.76951 * * *$ \\
\hline & $(.09988)$ & $(.09991)$ & $(.24926)$ & $(.25057)$ & $(.24728)$ & $(.24668)$ & $(.26589)$ \\
\hline Observations & 4139 & 4139 & 669 & 669 & 1079 & 1074 & 858 \\
\hline
\end{tabular}

Robust standard errors in parentheses

$* * * p<0.01,{ }^{* *} p<0.05, * p<0.1$ 
Notes on Table 4:

All regressions include the same controls as in Table 3.

CPS data refer to unemployment spells in progress at the Computer and Internet Supplement dates; all regressions include a control for elapsed duration prior to that date. CPS estimates use interval normal regression to account for the interval nature of the data.

NLSY97 data refer to unemployment spells immediately preceding the start of the respondent's current job. Interval normal regression is used to account for unemployment spells whose start date was before January 2005. NLSY97 regressions include fixed effects for the year the unemployment spell ended. 
Table 5: Determinants of Unemployment Durations, NLSY97: Robustness Checks

\begin{tabular}{|c|c|c|c|}
\hline & \multicolumn{3}{|c|}{ Dependent Variable } \\
\hline & (1) & $(2)$ & (3) \\
\hline Independent Variables: & Log(Duration) & Log(Duration) & $\begin{array}{c}\text { Re-employment } \\
\text { hazard }\end{array}$ \\
\hline Search Online & $\begin{array}{c}-.36823^{* *} \\
(.15786)\end{array}$ & $\begin{array}{c}-.34817^{* *} \\
(.15801)\end{array}$ & $\begin{array}{c}.25458 * * * \\
(.08843)\end{array}$ \\
\hline Home Internet Access & $\begin{array}{l}-.17557 \\
(.14989)\end{array}$ & $\begin{array}{l}-.12068 \\
(.16059)\end{array}$ & $\begin{array}{l}.09211 \\
(.09264)\end{array}$ \\
\hline AFQT & $\begin{array}{l}-.11726 \\
(.07548)\end{array}$ & $\begin{array}{l}-.10919 \\
(.07539)\end{array}$ & $\begin{array}{l}.04066 \\
(.04294)\end{array}$ \\
\hline Black & $\begin{array}{l}-.04461 \\
(.13702)\end{array}$ & $\begin{array}{l}-.03044 \\
(.13810)\end{array}$ & $\begin{array}{c}.00009 \\
(.08993)\end{array}$ \\
\hline Hispanic & $\begin{array}{l}.21625 \\
(.14027)\end{array}$ & $\begin{array}{c}.22322 \\
(.14043)\end{array}$ & $\begin{array}{l}-.13945 \\
(.09097)\end{array}$ \\
\hline Female & $\begin{array}{l}.21988 \\
(.14162)\end{array}$ & $\begin{array}{l}.24217^{*} \\
(.13960)\end{array}$ & $\begin{array}{c}-.25579 * * * \\
(.07759)\end{array}$ \\
\hline Involuntary Job Loss & $\begin{array}{l}.38917^{* * *} \\
(.13266)\end{array}$ & $\begin{array}{c}.38037^{* * *} \\
(.13207)\end{array}$ & $\begin{array}{c}-.14978 * * \\
(.07136)\end{array}$ \\
\hline Some high school & $\begin{array}{l}-.04876 \\
(.37243)\end{array}$ & $\begin{array}{l}-.03776 \\
(.37692)\end{array}$ & $\begin{array}{l}-.08234 \\
(.19988)\end{array}$ \\
\hline High School Degree & $\begin{array}{l}-.29855 \\
(.36001)\end{array}$ & $\begin{array}{l}-.29668 \\
(.36440)\end{array}$ & $\begin{array}{l}.12336 \\
(.18924)\end{array}$ \\
\hline Some College & $\begin{array}{c}-.26401 \\
(.36048)\end{array}$ & $\begin{array}{l}-.27874 \\
(.36464)\end{array}$ & $\begin{array}{c}.24047 \\
(.19336)\end{array}$ \\
\hline University Degree & $\begin{array}{l}-.22471 \\
(.37530)\end{array}$ & $\begin{array}{l}-.19360 \\
(.38017)\end{array}$ & $\begin{array}{l}.18526 \\
(.20038)\end{array}$ \\
\hline Married & $\begin{array}{c}-.68149 * * * \\
(.18666)\end{array}$ & $\begin{array}{c}-.65981^{* * *} \\
(.18689)\end{array}$ & $\begin{array}{c}.33448 * * * \\
(.11748)\end{array}$ \\
\hline Married*Female & $\begin{array}{c}.78174 * * * \\
(.26442)\end{array}$ & $\begin{array}{c}.76918 * * * \\
(.26426)\end{array}$ & $\begin{array}{c}-.39861^{* * *} \\
(.15436)\end{array}$ \\
\hline Observations & 858 & 858 & 858 \\
\hline
\end{tabular}

Robust standard errors in parentheses $* * * p<0.01, * * p<0.05, * p<0.1$

Notes on Table 5: Columns 1 and 2 are estimated by censored normal regression; coefficients show the change in log duration associated with a unit change in the regressor. Column 3 is estimated by Cox partial likelihood; coefficients show the change in the log of the re-employment hazard associated with a unit change in the regressor. In this table, "search online" is a continuous variable indicating the share of the respondent's search methods in which he/she used the Internet. 
Table 6: Determinants of Log Wage Changes between old and new job, NLSY97

\begin{tabular}{|c|c|c|c|}
\hline & (1) & $(2)$ & (3) \\
\hline Search online & $\begin{array}{l}-.03456 \\
(.04734)\end{array}$ & $\begin{array}{l}-.04178 \\
(.04908)\end{array}$ & $\begin{array}{l}-.00138 \\
(.05827)\end{array}$ \\
\hline Home Internet Access & & $\begin{array}{l}.04504 \\
(.04713)\end{array}$ & $\begin{array}{l}.06001 \\
(.05371)\end{array}$ \\
\hline AFQT & & & $\begin{array}{l}-.01396 \\
(.03072)\end{array}$ \\
\hline Black & $\begin{array}{l}.02075 \\
(.04320)\end{array}$ & $\begin{array}{l}.02527 \\
(.04330)\end{array}$ & $\begin{array}{l}.05027 \\
(.05306)\end{array}$ \\
\hline Hispanic & $\begin{array}{c}.06008 \\
(.04044)\end{array}$ & $\begin{array}{c}.05959 \\
(.04056)\end{array}$ & $\begin{array}{l}.07545^{*} \\
(.04562)\end{array}$ \\
\hline Female & $\begin{array}{l}-.03512 \\
(.04739)\end{array}$ & $\begin{array}{l}-.03582 \\
(.04779)\end{array}$ & $\begin{array}{l}-.02906 \\
(.05599)\end{array}$ \\
\hline Involuntary Job Loss & $\begin{array}{c}-.11921 * * * \\
(.04222)\end{array}$ & $\begin{array}{c}-.11995 * * * \\
(.04246)\end{array}$ & $\begin{array}{c}-.11544 * * \\
(.04782)\end{array}$ \\
\hline Some high school & $\begin{array}{c}.12062 \\
(.07878)\end{array}$ & $\begin{array}{c}.11998 \\
(.07880)\end{array}$ & $\begin{array}{l}.05891 \\
(.08436)\end{array}$ \\
\hline High School Degree & $\begin{array}{l}.05224 \\
(.07664)\end{array}$ & $\begin{array}{c}.04755 \\
(.07675)\end{array}$ & $\begin{array}{c}.00351 \\
(.08928)\end{array}$ \\
\hline Some College & $\begin{array}{c}.09977 \\
(.08002)\end{array}$ & $\begin{array}{l}.08715 \\
(.07947)\end{array}$ & $\begin{array}{c}.07101 \\
(.09200)\end{array}$ \\
\hline University Degree & $\begin{array}{c}.33666 * * * \\
(.07905)\end{array}$ & $\begin{array}{c}.32030 * * * \\
(.08004)\end{array}$ & $\begin{array}{c}.32638 * * * \\
(.09992)\end{array}$ \\
\hline Married & $\begin{array}{l}-.05116 \\
(.05949)\end{array}$ & $\begin{array}{l}-.05285 \\
(.05963)\end{array}$ & $\begin{array}{l}-.02209 \\
(.06654)\end{array}$ \\
\hline Married*Female & $\begin{array}{c}.07301 \\
(.07958)\end{array}$ & $\begin{array}{l}.07544 \\
(.07958)\end{array}$ & $\begin{array}{c}.02802 \\
(.08919)\end{array}$ \\
\hline Observations & 1023 & 1018 & 816 \\
\hline
\end{tabular}

Robust standard errors in parentheses $* * * p<0.01, * * p<0.05, * p<0.1$

Notes on Table 6: Sample and Covariates are Identical to Table 4. 


\section{Appendix A: NLSY survey questions on job search methods}

1. "Unemployed" Sample. The following survey question was asked of all respondents with a current job gap; our "unemployed" sample consists of the subset of this group who used at least one active job search method:

"Please look at this list of activities that people sometime use to find a job. Which of them did you use to look for work?”

2. "Employed" Sample. The following survey question was asked of all respondents with a current long-term job, where "long-term" is defined by the NLSY as longer than 3 months. Our "employed searchers" sample consists of all persons who were asked this question, and who who listed at least one active job search activity:

"In the past three months, have you done anything to look for work? Please don't include any job search activities you've already told me about." If the answer is yes, the respondent is asked "Please look at this list of activities that people sometimes use to try to find a job. Which of these have you done to look for work?

3. Sample of "Currently Employed, during search for current job". The following survey question was also asked of all respondents who are currently employed in a long-term job. We use it to construct our sample of the unemployment spells that ended with the current job, and to measure the search methods used during those spells:

"Think back to when you found your current job with [employer name]. Please look at this list of activities that people sometimes use to try to find a job. Which of these did you do to look for work at that time?”

After each of these questions, respondents were presented with the list of the 12 CPS search activities (12 in total) shown in Table 3. After checking off all methods that they used, respondents were then asked, "Of the methods that you used, which of them used the Internet, for example, e-mail or a web-site?” 
Appendix B: Supplementary Tables

Table B1: Search Methods of Employed Jobseekers

\begin{tabular}{|c|c|c|c|c|}
\hline Method & $\begin{array}{c}\text { (1) } \\
\text { Share of workers } \\
\text { using method off } \\
\text { line }\end{array}$ & $\begin{array}{l}\text { (2) } \\
\text { Share of workers } \\
\text { using method on } \\
\text { line }\end{array}$ & $\begin{array}{c}(3) \\
\text { Share of workers } \\
\text { using method, total } \\
(1+2)\end{array}$ & $\begin{array}{c}(4) \\
\text { Share of method } \\
\text { users doing so on } \\
\text { line }(2 / 3)\end{array}$ \\
\hline \multicolumn{5}{|l|}{ Active Search Methods: } \\
\hline 1. Contacted employer directly & 0.15 & 0.27 & 0.42 & 0.64 \\
\hline 2. Contacted public employment agency & 0.02 & 0.10 & 0.12 & 0.83 \\
\hline 3. Contacted private employment agency & 0.04 & 0.06 & 0.10 & 0.60 \\
\hline 4. Contacted friends or relatives & 0.30 & 0.17 & 0.47 & 0.36 \\
\hline 5. Contacted school/university employment center & 0.01 & 0.07 & 0.08 & 0.88 \\
\hline 6. Sent out resumes or filled out applications & 0.10 & 0.56 & 0.66 & 0.85 \\
\hline 7. Checked unions or professional registers & 0.01 & 0.02 & 0.03 & 0.67 \\
\hline 8. Placed or answered ads & 0.05 & 0.19 & 0.24 & 0.79 \\
\hline 9. Other active methods & 0.02 & 0.04 & 0.06 & 0.67 \\
\hline A: Total active search methods (sum of (1)-(9)) & 0.70 & 1.48 & 2.18 & 0.68 \\
\hline \multicolumn{5}{|l|}{ Passive Search Methods: } \\
\hline 10. Looked at ads & 0.10 & 0.39 & 0.49 & 0.80 \\
\hline 11. Attended job training programs or courses & 0.01 & 0.01 & 0.02 & 0.50 \\
\hline 12. Other passive methods & 0.03 & 0.00 & 0.03 & 0.00 \\
\hline B: Total passive search methods (sum of (10)-(12)) & 0.14 & 0.40 & 0.54 & 0.69 \\
\hline Total number of search methods $(A+B)$ & 0.84 & 1.88 & 2.72 & 0.69 \\
\hline Share of active methods in total search $(A /(A+B))$ & 0.83 & 0.79 & 0.80 & - \\
\hline
\end{tabular}

Notes on Table B1: Sample size of employed jobseekers is 441. Sample weights are applied. 
Table B2: Search Methods during Previous Unemployment Spell

\begin{tabular}{|c|c|c|c|c|}
\hline Method & $\begin{array}{l}\text { (1) } \\
\text { Share of workers } \\
\text { using method off } \\
\text { line }\end{array}$ & $\begin{array}{c}(2) \\
\text { Share of workers } \\
\text { using method on } \\
\text { line }\end{array}$ & $\begin{array}{c}(3) \\
\text { Share of workers } \\
\text { using method, total } \\
(1+2)\end{array}$ & $\begin{array}{c}(4) \\
\text { Share of method } \\
\text { users doing so on } \\
\text { line }(2 / 3)\end{array}$ \\
\hline \multicolumn{5}{|l|}{ Active Search Methods: } \\
\hline 1. Contacted employer directly & 0.34 & 0.25 & 0.59 & 0.42 \\
\hline 2. Contacted public employment agency & 0.04 & 0.05 & 0.09 & 0.56 \\
\hline 3. Contacted private employment agency & 0.03 & 0.03 & 0.06 & 0.50 \\
\hline 4. Contacted friends or relatives & 0.31 & 0.10 & 0.41 & 0.24 \\
\hline 5. Contacted school/university employment center & 0.03 & 0.06 & 0.09 & 0.67 \\
\hline 6. Sent out resumes or filled out applications & 0.15 & 0.31 & 0.46 & 0.67 \\
\hline 7. Checked unions or professional registers & 0.01 & 0.01 & 0.02 & 0.50 \\
\hline 8. Placed or answered ads & 0.05 & 0.10 & 0.15 & 0.67 \\
\hline 9. Other active methods & 0.02 & 0.02 & 0.04 & 0.50 \\
\hline A: Total active search methods (sum of (1)-(9)) & 0.98 & 0.93 & 1.91 & 0.49 \\
\hline \multicolumn{5}{|l|}{ Passive Search Methods: } \\
\hline 10. Looked at ads & 0.08 & 0.18 & 0.26 & 0.69 \\
\hline 11. Attended job training programs or courses & 0.02 & 0.02 & 0.04 & 0.50 \\
\hline 12. Other passive methods & 0.02 & 0.00 & 0.02 & 0.00 \\
\hline B: Total passive search methods (sum of (10)-(12)) & 0.12 & 0.20 & 0.32 & 0.63 \\
\hline Total number of search methods $(A+B)$ & 1.10 & 1.13 & 2.23 & 0.51 \\
\hline Share of active methods in total search $(A /(A+B))$ & 0.89 & 0.82 & 0.86 & - \\
\hline
\end{tabular}

Notes on Table B2: Sample size of employed workers is 1,166. Sample weights are applied. 
Table B3: Determinants of Internet Job Search in Alternative Samples, NLSY97

\begin{tabular}{|c|c|c|c|c|c|c|}
\hline & \multicolumn{3}{|c|}{ Sample of Employed Jobseekers } & \multicolumn{3}{|c|}{ Sample of Previous Unemployment Spells } \\
\hline & $(1)$ & $(2)$ & (3) & $(4)$ & $(5)$ & $(6)$ \\
\hline \multirow[t]{2}{*}{ Home Internet Access } & & $.16159 * * *$ & $.17487^{* *}$ & & $.16625 * * *$ & $.16451 * * *$ \\
\hline & & $(.05849)$ & $(.07062)$ & & $(.03232)$ & $(.03589)$ \\
\hline \multirow[t]{2}{*}{ AFQT } & & & .03131 & & & $.03472 *$ \\
\hline & & & $(.02587)$ & & & $(.01935)$ \\
\hline \multirow[t]{2}{*}{ Black } & -.02427 & -.00864 & .03271 & .02243 & .04057 & $.08253^{* *}$ \\
\hline & $(.05172)$ & $(.05367)$ & $(.06188)$ & $(.03404)$ & $(.03343)$ & $(.04016)$ \\
\hline \multirow[t]{2}{*}{ Hispanic } & -.03697 & -.03559 & -.00188 & .03639 & .03307 & .03065 \\
\hline & $(.05829)$ & $(.05455)$ & $(.06512)$ & $(.03468)$ & $(.03390)$ & $(.04155)$ \\
\hline \multirow[t]{2}{*}{ Female } & -.05142 & -.04933 & -.07420 & $.09528 * * *$ & $.09654 * * *$ & $.07648 * *$ \\
\hline & $(.04975)$ & $(.04976)$ & $(.05540)$ & $(.03175)$ & $(.03152)$ & $(.03467)$ \\
\hline \multirow[t]{2}{*}{ Involuntary Job Loss } & -.03031 & -.03320 & -.05524 & $.08414 * * *$ & $.07990 * * *$ & $.07944 * *$ \\
\hline & $(.04451)$ & $(.04488)$ & $(.05141)$ & $(.02998)$ & $(.02969)$ & $(.03302)$ \\
\hline \multirow[t]{2}{*}{ Some high school } & .21168 & .20930 & .07749 & .04974 & .04194 & $.10984^{*}$ \\
\hline & $(.16681)$ & $(.15528)$ & $(.12643)$ & $(.06779)$ & $(.06433)$ & $(.06224)$ \\
\hline \multirow[t]{2}{*}{ High School Degree } & .22717 & .23433 & .02226 & $.14129 * *$ & $.12148 *$ & $.16657^{* * *}$ \\
\hline & $(.16321)$ & $(.15058)$ & $(.12473)$ & $(.06757)$ & $(.06430)$ & (.06184) \\
\hline \multirow[t]{2}{*}{ Some College } & $.31618^{* *}$ & $.30043 * *$ & .07637 & $.20826 * * *$ & $.15671^{* *}$ & $.18347^{* * *}$ \\
\hline & $(.16034)$ & $(.14827)$ & $(.11605)$ & $(.06829)$ & $(.06620)$ & $(.06413)$ \\
\hline \multirow[t]{2}{*}{ University Degree } & $.39999 * *$ & $.35706 * *$ & .15643 & $.47260 * * *$ & $.39386 * * *$ & $.37849 * * *$ \\
\hline & $(.15587)$ & $(.14431)$ & $(.11066)$ & $(.06709)$ & $(.06663)$ & $(.06687)$ \\
\hline \multirow[t]{2}{*}{ Married } & .05673 & .04555 & .09156 & -.00441 & -.00817 & -.01700 \\
\hline & $(.05557)$ & $(.05374)$ & $(.05789)$ & $(.04248)$ & $(.04201)$ & $(.04326)$ \\
\hline \multirow[t]{2}{*}{ Married*Female } & -.08475 & -.06419 & -.09351 & .00272 & .00836 & .05008 \\
\hline & $(.09146)$ & $(.08755)$ & $(.09655)$ & $(.05889)$ & $(.05777)$ & $(.06230)$ \\
\hline Observations & 351 & 348 & 282 & 1079 & 1074 & 858 \\
\hline
\end{tabular}

Robust standard errors in parentheses

$$
* * * p<0.01, * * p<0.05, * p<0.1
$$

Notes on Table B3: Dependent variable equals one if the respondent engaged in any Internet job search, and zero otherwise. All regressions control for age effects (ten-year bins in columns 1 and 2, and single years of age in columns 3-7), and fixed effects for whether the respondent used each of the twelve CPS job search methods. 
Table B4: Sample Means, Unemployment Duration Regression Regressions

\begin{tabular}{lll}
\hline & CPS & NLSY97 \\
\hline Search online & .242 & .550 \\
Home Internet Access & .286 & .740 \\
Black & .212 & .157 \\
Hispanic & .164 & .148 \\
Female & .521 & .495 \\
Involuntary Job Loss & .366 & .250 \\
Some high school & .173 & .141 \\
High School Degree & .353 & .228 \\
Some College & .265 & .211 \\
University Degree & .161 & .381 \\
Married & .281 & .289 \\
Observations & 669 & \\
\hline
\end{tabular}

Notes on Table B4: Mean unemployment duration in the NLSY97 is 19.8 weeks. Unemployment durations in the CPS are only available in broad categories, so a mean cannot be calculated directly. Predicted mean duration following the interview date for the model in column 4 of Table 4 is 7.9 weeks. 
Figure 1: Predicted Survivor Curves at Zero versus Mean Level of Internet Search Intensity

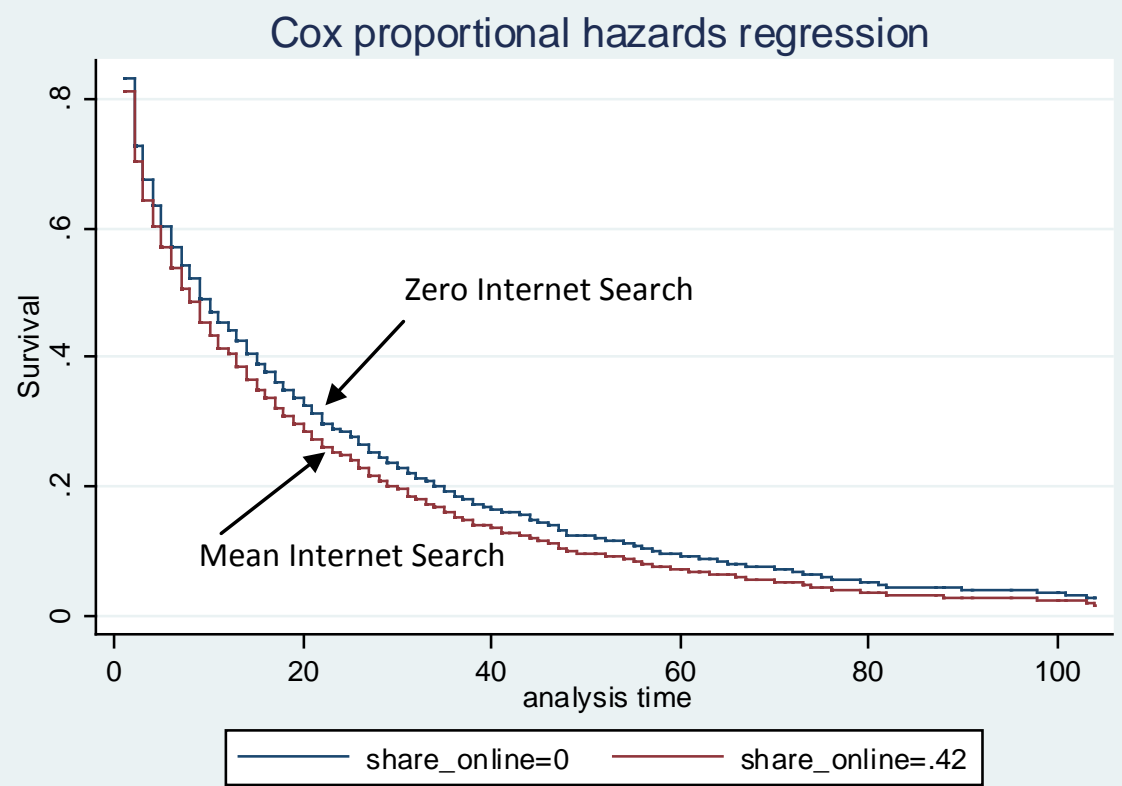

